\title{
Assessment of Heavy Metal Enrichment and Degree of Contamination Around the Copper-Nickel Mine in the Selebi Phikwe Region, Eastern Botswana
}

\author{
Alfred Sello Likuku", ${ }^{1, *}$ Khumoetsile B. Mmolawa ${ }^{2}$, Gilbert Kabelo Gaboutloeloe ${ }^{2}$ \\ ${ }^{1}$ Department of Basics Sciences, Botswana College of Agriculture, Gaborone, Botswana \\ ${ }^{2}$ Department of Agricultural Engineering and Land Planning, Botswana College of Agriculture, Gaborone, Botswana \\ *Corresponding Author: alikuku@bca.bw
}

Copyright (C 2013 Horizon Research Publishing All rights reserved.

\begin{abstract}
This paper focuses on heavy metal $(\mathrm{Co}, \mathrm{Cu}$, $\mathrm{Fe}, \mathrm{Pb}, \mathrm{Mn}, \mathrm{Ni}$ and $\mathrm{Zn}$ ) enrichment and degree of contamination in the soils windward of the Selebi Phikwe copper and nickel mine (eastern Botswana). Pollution by these metals was examined using several calculation methods: enrichment factors, modified degree of contamination, pollution load index and geoaccumulation index. Enrichment factors were further assessed by comparing present day soil metal contents obtained using actual Fe content in standard earth material obtained from literature with that measured in soils sampled from areas adjacent to the site of concern to represent "uncontaminated" background concentrations. The latter method was found to be the most relevant and the normalised enrichment values demonstrate moderate enrichment of $\mathrm{Cu}$ and $\mathrm{Ni}$. The proposed modified calculation method of degree of contamination, which involves determination of arithmetic mean of contamination factors by individual studied metals, revealed moderate contamination by metals. The PLI, which basically is a measure of site quality, indicated deterioration due to metal contamination. These results were further supported by values obtained from indices of geoaccumulation method of pollution assessment. Principal component analysis at windward site of the mine extracted two major components: 1 . high positive loading of $\mathrm{Pb}, \mathrm{Ni}$, $\mathrm{Cu}$ and $\mathrm{Zn}$ associated with anthropogenic influence by smelter emissions and 2.high positive loadings of $\mathrm{Co}, \mathrm{Mn}$ and $\mathrm{Fe}$ are associated with contributions from natural processes. This evaluation would serve to create consistent calculation methods as a contribution towards building a consensus on methodologies applicable to the study of polluted soils.
\end{abstract}

Keywords Enrichment Factors, Degree of Contamination, Pollution Load Index, Geoaccumulation Index, Principal Component Analysis

\section{Introduction}

The study of heavy metal deposition and accumulation is of increasing interest because of the awareness that heavy metals present in soils may have negative consequences on human health and on the environment [1-4]. Heavy metals in soils may be immobile or not, depending on the soil characteristics which in turn influence chemical speciation and solubility. For example Reboredo[5] showed that approximately $50 \%$ of the total $\mathrm{Zn}$ in soil marshes is extracted by distilled water indicating that the element is not neither in an insoluble form nor strongly bound by organic matter, thus enhancing the mobility of $\mathrm{Zn}$. Conversely, the mobility of $\mathrm{Cu}$ is weak since the metal forms strong complexes with fulvic and humic acids. Cadmium, for example, was easily accumulated by the roots of Halimione portulacoides and translocated to the leaves despite the low levels observed in the substrata, emphasizing the great mobility of the element [6]. A contaminant that is immobile in soils and essentially not absorbed by plants will have an impact through more direct pathways such as geophagy and inhalation of dust. [7].

Environmental pollution by heavy metals is due to many activities whereas in the soil system, pollution by heavy metals is mainly due to both natural processes such as weathering of minerals and anthropogenic activities related to industry, agriculture, burning of fossil fuels, vehicular emission, mining and metallurgical processes and their waste disposal. In the study of environmental contamination, a common approach to estimate how much the soil is impacted (naturally or anthropogenically) with heavy metal is to evaluate the Enrichment Factor $(E F)$ for metal concentrations above uncontaminated background or reference levels [8]. Pollution will be measured as the amount of the sample metal enrichment above the concentrations present in the reference material [9].

Comprehensive methods for identifying and assessing 
severity of soil contamination by heavy metals have been introduced for the past decades. One approach to characterising pollution signals is to compare element concentrations and establish guidelines for environmental media. For example, Long et al.[10] established guidelines comprised of three degrees of adverse effects that can be defined from two guideline concentration values: Less than Effects Range Low; Between Effects Range Low and Effects Range Median; and greater than Effects Range Median. An alternative method used to characterise degree of anthropogenic pollution is to establish the $E F$ approach reported in Chester et al.[11], Gaiero et al.[12], Sutherland et al.[13] and Mmolawa et al.[14]. Several other methods for determining extent of pollution in soils and sediments have been established by various authors in many parts of the world [9,15-17].

A large body of literature focused on environmental pollution by series of contaminants is available [9,15-17], however, there is a considerable variation in how the degree of contamination on a given site is being quantified. In this study, an attempt has been made to: 1) review various methods for establishing baseline concentrations of $\mathrm{Co}, \mathrm{Cu}$, $\mathrm{Fe}, \mathrm{Pb}, \mathrm{Mn}, \mathrm{Ni}$ and $\mathrm{Zn} ; 2$ ) calculate the extent of contamination by these metals around the copper-nickel mine in the Selebi Phikwe region; 3) apply the obtained baseline values in the available calculation methods so as to assess and compare degree of metal contamination and 4) propose an approach for estimating the overall degree of enrichment in series of pollutants. It is envisaged that results of this study will provide consistent calculation methods as a contribution towards building a consensus on methodologies applicable to the study of polluted soils.

\section{Materials and Methods}

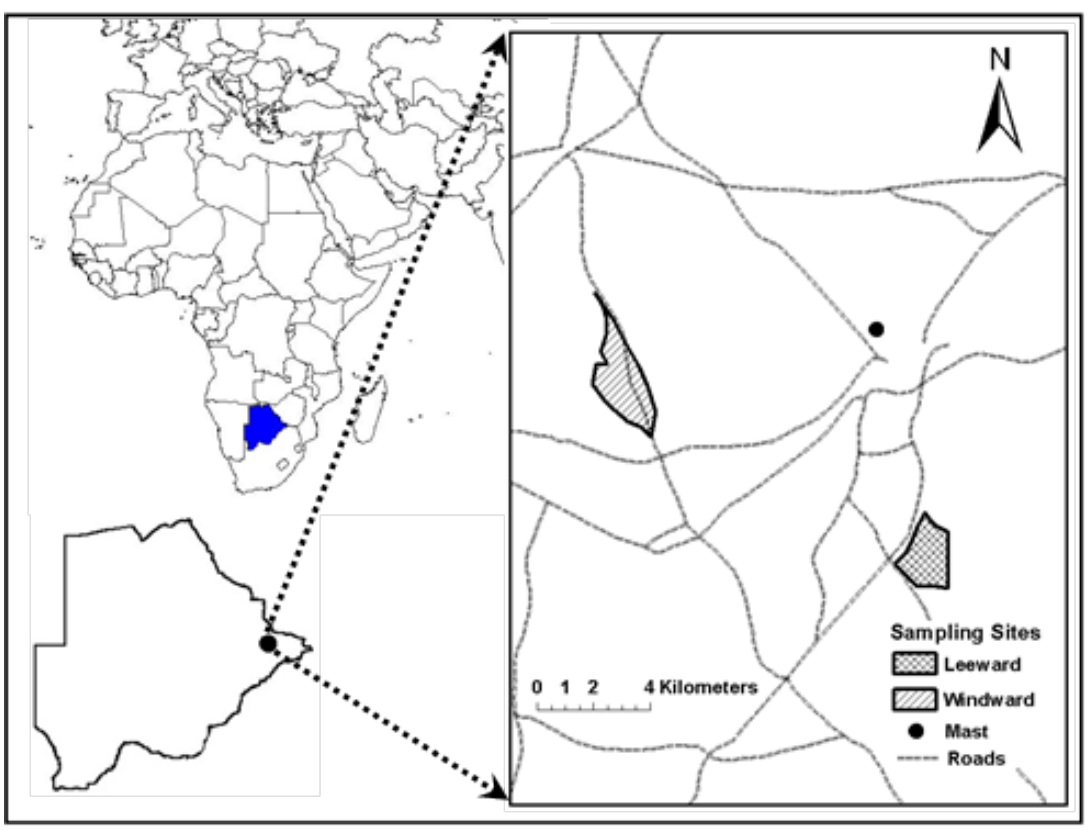

Figure 1. A map showing sampled areas2.2. Sampling Technique and Preparation
The study was conducted in Selebi Phikwe (longitudes $27.8^{\circ}$ and $27.9^{\circ}$ East; latitudes $22.0^{\circ}$ and $22.9^{\circ}$ South). The Selebi Phikwe Copper-Nickel mine started its full operations more than four decades ago, in 1973. No environmental mitigation impact assessment was carried out; hence, no mitigation programs were put in place. Although it was planned that the gases from the mine would be carried away by the prevailing winds from the settlement, the planning was unsuccessful since other settlements, particularly on the western side of the mining industry, where predominant winds always blow, are located in the direction of the major pollutant impacts. Furthermore, more than 40 years of intense $\mathrm{Cu}-\mathrm{Ni}$ mining and ore processing has left enormous pollution related to the disposal sites for the mining /smelting waste such as mine tailings, slags and to the continuous deposition of smelter stack particulates in the soil systems. The soils of the study area are classified as Eutric Regosols and Haplic Luvisols [18].

The climatic conditions of the study area are (i) a hot and rainy season with sub-tropical thunderstorms (November-March), (ii) a cool dry season (April-August) and (iii) a hot season with practically no rain (September-November). The annual average rainfall in Selebi Phikwe is $600 \mathrm{~mm}$ throughout the year. The winds are predominant from the south-easterly quadrant [19]. The majority of the land is covered with sparse grass, shrubs and trees, mainly Aristida conjesta, Grewia flava, and Colophospermum mopane, respectively. According to the villagers, agricultural activities such as crop cultivation are being slowly abandoned, however, small stock and cattle rearing is still practiced. Figure 1 shows a map of Botswana and the sampling sites in this study. 


\subsection{Sampling Technique and Preparation}

Surface soils of up to10 $\mathrm{cm}$ deep were collected using hand driven stainless steel corers, following a simple random and judgmental sampling technique. The soils were sampled both from the windward and leeward sides of the smelter stack. The windward site is assumed to be a polluted whereas the leeward site is assumed to be sheltered from pollution by smelter emissions. Exact locations for all sampled sites were determined using global positioning system and entered into a geographical information system for data processing.

In the laboratory, the collected soil samples were air-dried to constant weight and then sieved through a $500 \mu \mathrm{m}$ stainless steel mesh wire. Samples of $0.50 \mathrm{~g}$ were digested in $20 \mathrm{ml}$ freshly prepared aqua regia $\left(1: 3 \mathrm{HNO}_{3}: \mathrm{HCl}\right)$ on a hot plate for 3 hours, then evaporated and analysed for metal concentration. Standard reference material was prepared using stock solution from SAARCHM and MERCH and used to have a check on the accuracy of the results. The total concentrations of $\mathrm{Co}, \mathrm{Cu}, \mathrm{Fe}, \mathrm{Pb}, \mathrm{Mn}, \mathrm{Ni}$ and $\mathrm{Zn}$ in filtrates were then determined using a Flame Atomic Absorption Spectrometer (Varian SpectrAA 220 FS) using air acetylene flame.

\subsection{Data Analysis}

In order to assess heavy metal enrichment and degree of contamination in soils, analytical data were subjected to pollution calculation methods expressed in (1-8) with the aim of deriving realistic estimates for the amount of contamination that has impacted soils around the Selebi Phikwe mine.

\subsubsection{Enrichment Factor, $E F$}

The enrichment factor was calculated using the formula originally introduced by Buat-Menard and Chesselet[20] as shown in (1).

$$
E F=\frac{\left(C_{n} / C_{r e f}\right)_{\text {sample }}}{\left(B_{n} / B_{r e f}\right)}
$$

where $C_{n}$ (sample) is the concentration of the examined chemical element in the examined environment, $C_{r e f}$ (sample) is the concentration of the examined chemical element in the reference environment, $B_{n}$ is the concentration of the reference chemical element in the examined environment and $B_{r e f}$ is the concentration of the reference element in the reference environment. In this work, the authors followed the earlier environmental work of Salomons and Förstner[21]. by comparing present day soil metal concentrations with standard earth materials in average shale [22] and average crustal values $[23,24]$. Iron $(\mathrm{Fe})$ was used as the reference element at a crustal [22] and shale [25] abundance values of $47200 \mathrm{mg} / \mathrm{kg}$ and $35000 \mathrm{mg} / \mathrm{kg}$, respectively.

Data was reanalysed using heavy metal concentrations in soils obtained from a leeward site of the $\mathrm{Cu}-\mathrm{Ni}$ smelter area (therefore assumed to mimic pre-industrial data), and EFs were calculated using the formula reported in Chester[11] and Sutherland[13] given in (2).

$$
E F=\frac{C_{\mathrm{m}} \text { Sample }}{\left(\text { Median } C_{\mathrm{m}} \text { Background }+2 \times \operatorname{MAD} C_{\mathrm{m}} \text { Background }\right)}
$$

$C_{\mathrm{m}}$ Sample is the concentration of a given metal at contaminated (windward) sites. Median $C_{\mathrm{m}}$ Background is median concentration of an element in the background (leeward) soil sample and MAD $C_{\mathrm{m}}$ Background is the Median Absolute Deviation from the Median, defined in (3).

$$
\operatorname{MAD}=\operatorname{median}\left(\left|x_{i}-\operatorname{median}_{j}\left(x_{j}\right)\right|\right)
$$

\subsubsection{Modified Degree of Contamination, $\mathrm{mCd}$}

The degree of contamination in soil by metals was calculated based on the method presented by Abrahim[26] shown in (4).

$$
m C_{d}=\frac{1}{N} \sum_{i=1}^{N} C F_{i}
$$

where $N$ is the number of elements analysed and $C F$ is the contamination factor calculated as shown in (5).

$$
C F=\frac{C_{\mathrm{m}} \text { Sample }}{C_{\mathrm{m}} \text { Background }}
$$

where $C_{\mathrm{m}}$ Sample and Median $C_{\mathrm{m}}$ Background in (5) are as described before.

It is worth noting that (4) is a modified and generalized form of the degree of contamination $\left(C_{d}\right)$ formula, in (6), proposed by Håkanson[15].

$$
C_{d}=\sum_{i=1}^{N} C F_{i}
$$

The aim of calculating contamination factor is to provide a measure of the degree of overall contamination of surface layers in a sampled site, however, the formula by Håkanson[15] is constrained to the seven specific metals (As, $\mathrm{Cd}, \mathrm{Cu}, \mathrm{Cr}, \mathrm{Hg}, \mathrm{Pb}, \mathrm{Zn}$ ) and the persistent organic pollutant, polychlorinated biphenyl (PCB) analysed in his study. Furthermore, all the eight species (seven metals and the PCB) must be analysed in order to determine the correct $C_{d}$ that would satisfy classification terminologies specified in his study.

\subsubsection{Pollution Load Index, $P L I$}

The pollution load index, proposed by Thomlinson et al.[27], was calculated using (7).

$$
P L I=\left(C F_{1} \times C F_{2} \times C F_{3} \times \ldots \times C F_{N}\right)^{1 / N}
$$

where $N$ is the number of metals studied and $C F$ is the contamination factor calculated as described in (4). The PLI is able to give an estimate of the metal contamination status and the necessary action that should be taken. A $P L I<1$ 
denote perfection; $P L I=1$ present that only baseline levels of pollutants are present and $P L I>1$ would indicate deterioration of site quality [27]. In this study, the authors propose that a $P L I$ value of $\geq 1$ indicates an immediate intervention to ameliorate pollution; $0.5 \leq P L I<1$ suggests that more detailed study is needed to monitor the site, whilst a value of $<0.5$ indicates that there is no need for drastic rectification measures to be taken.

\subsubsection{Geoaccumulation Index, $I_{\text {geo }}$}

The index of geoaccumulation actually enables the assessment of contamination by comparing the current levels of metal concentrations and the original pre-industrial concentrations in the soils. Effects of mining activities were assessed following the geoaccumulation index approach proposed by Müller[28], as given in (8).

$$
I_{\text {geo }}=\log _{2}\left[\frac{C_{\mathrm{m}} \text { Sample }}{\left(1.5 \times C_{m} \text { Background }\right)}\right]
$$

The factor 1.5 is introduced in (8) to minimise the effect of possible variations in the background values, $C_{\mathrm{m}}$ Background, which may be attributed to lithogenic variations in soils.

\subsection{Statistical Analysis}

Correlation of different elements in soil samples were calculated by the non-parametric Spearman rank method. To help in the identification of different metal types, Principal Component $(P C)$ analysis was performed to establish possible factors that contribute towards the metal concentrations and source apportionment. The number of significant principal components was selected on the basis of Varimax orthogonal rotation with Kaiser Normalisation at eigenvalues greater than 1 .

\section{Results and Discussion}

\subsection{Concentrations of the Studied Elements}

Concentrations of $\mathrm{Co}, \mathrm{Cu}, \mathrm{Fe}, \mathrm{Pb}, \mathrm{Mn}, \mathrm{Ni}$ and $\mathrm{Zn}$ in leeward and windward sites of the Selebi Phikwe mining copper-nickel smelter stack are presented in Table 1.

Mean concentrations of $\mathrm{Cu}, \mathrm{Fe}, \mathrm{Ni}$ and $\mathrm{Pb}$ in superficial soil at the windward sites exceeded $(P<0.05)$ those at the leeward sites. Enhanced mean concentrations of the 4 metals at the windward site are attributed to deposition of toxic substances associated with copper-nickel smelter emissions from the mine. Barcan[29] reported enriched concentrations of nickel, cobalt, copper, lead, zinc and arsenic in metallurgical dust emissions originating from several copper-nickel smelter plants in Russia. On the other hand, mean $\mathrm{Mn}$ and $\mathrm{Zn}$ concentrations in both leeward and windward sites were statistically the same. Manganese, like other lithophile elements, is relatively abundant with an average upper crustal abundance of $600 \mathrm{mg} / \mathrm{kg}$ and a bulk continental crust average of $1400 \mathrm{mg} / \mathrm{kg}$ [25]. Thus, its natural abundance vastly dominates its anthropogenic input. Iron was also expected to exhibit insignificant difference in mean concentrations between the two sites due to its natural abundance. However, contrasting results obtained from this study may need a more detailed investigation to clarify the difference. A similar argument holds for lack of significant difference in mean concentrations of $\mathrm{Zn}$ between the two sites. It is difficult to justify the enhanced mean concentration of $\mathrm{Co}$ at leeward side of the smelter as compared the windward site.

Table 1. Basic statistical data of the 7 elements measured in this study

\begin{tabular}{|c|c|c|c|c|c|}
\hline \multirow{2}{*}{ Metal } & \multicolumn{2}{|c|}{ Leeward soils (mg/kg) } & \multicolumn{2}{|c|}{ (Windward) soils (mg/kg) } & \multirow{2}{*}{$\begin{array}{c}P \text {-value } \\
\text { (2 tailed) }\end{array}$} \\
\hline & $(\min -\operatorname{Max})$ & Mean $(n=14)$ & $(\min -M a x)$ & Mean $(n=23)$ & \\
\hline Co & $(0.45-1.10)$ & $0.62 \pm 0.16$ & $(0.02-0.53)$ & $0.22 \pm 0.12$ & 0.000 \\
\hline $\mathrm{Cu}$ & $(0.18-0.66)$ & $0.34 \pm 0.13$ & $(0.78-4.99)$ & $2.16 \pm 1.03$ & 0.000 \\
\hline $\mathrm{Fe}$ & $(45-298)$ & $189 \pm 77$ & $(25-536)$ & $264 \pm 119$ & 0.026 \\
\hline $\mathrm{Mn}$ & $(1.47-7.44)$ & $3.50 \pm 1.40$ & $(0.56-8.63)$ & $3.55 \pm 2.30$ & 0.931 \\
\hline $\mathrm{Ni}$ & $(0.18-0.78)$ & $0.32 \pm 0.16$ & $(0.19-2.77)$ & $1.15 \pm 0.71$ & 0.000 \\
\hline $\mathrm{Pb}$ & $(0.02-0.42)$ & $0.16 \pm 0.12$ & $(0.13-0.85)$ & $0.34 \pm 0.19$ & 0.004 \\
\hline $\mathrm{Zn}$ & $(0.44-0.84)$ & $0.55 \pm 0.12$ & $(0.30-1.59)$ & $0.66 \pm 0.34$ & 0.146 \\
\hline
\end{tabular}




\subsubsection{Enrichment Factors}

Four different methods (method A through method D) were used to compute metal enrichment factors at windward site of the smelter stack shown in Table 2. Enrichment factor categories proposed by Sutherland[13] were used as follows: $E F<2$ = deficiently to minimal enrichment, $2 \leq E F<5=$ moderate enrichment, $5 \leq E F<20=$ significant enrichment, $20 \leq E F<40=$ very high enrichment and $E F \geq 40=$ extremely high enrichment.

Table 2. Enrichment factors of the 7 elements based on 4 different (methods A through method D) background values

\begin{tabular}{cccccc} 
& \multicolumn{6}{c}{$\mathrm{A}$} & $\mathrm{B}$ & $\mathrm{C}$ & $\mathrm{D}$ & P-value \\
\hline & 2.11 & 1.19 & 1.24 & 0.28 & 0.00 \\
$\mathrm{Co}$ & 8.57 & 5.20 & 11.44 & 4.17 & 0.00 \\
$\mathrm{Cu}$ & 1.00 & 1.00 & 1.00 & 0.88 & 0.73 \\
$\mathrm{Fe}$ & 0.75 & 0.50 & 0.66 & 0.68 & 0.22 \\
$\mathrm{Mn}$ & 3.03 & 2.03 & 2.54 & 2.28 & 0.16 \\
$\mathrm{Ni}$ & 3.01 & 3.58 & 3.02 & 1.01 & 0.00 \\
$\mathrm{~Pb}$ & 1.25 & 1.26 & 1.36 & 0.97 & 0.20 \\
$\mathrm{Zn}$ & &
\end{tabular}

Method A: Using (1) and average shale values [22]

Method B: Using (1) average crustal values [23]

Method C: Using (1) average crustal values [24]

Method D: Using (2) \& (3) and the background values obtained from study site

It is evident from the results that based on all the 4 methods, only $\mathrm{Cu}$ and $\mathrm{Ni}$ exhibit moderate to significant enrichment. However, on the basis of comparison between methods, there are considerable differences $(P=0.00)$ in $E F$ values for $\mathrm{Co}, \mathrm{Cu}$ and $\mathrm{Pb}$. A closer look at the $E F$ values shows that normalisation with continental shale (Method A) and crustal abundance values (Methods $\mathrm{B}$ and $\mathrm{C}$ ) result in considerably high $(P=0.00) E F$ for $\mathrm{Co}, \mathrm{Cu}$ and $\mathrm{Pb}$ compared to average values determined using 'pristine' background metal content values from the adjacent study site. Post-hoc least square difference (output table of which is not included in the manuscript) also exhibits a number of inter-method mean differences, except for $\mathrm{Fe}$, since this metal was used for normalisation.

In view of the above conflicting $E F$ values, it is clear that the calculation of $E F$ values using standard earth materials need to be interpreted with caution. For the purpose of this study, the most appropriate and relevant procedure is to use reference material determined from uncontaminated backgrounds obtained from soils from the area of interest. Method D (2) is advantageous in that it assesses heavy metals in background soils obtained several meters within the site of concern so as to establish reference values that are mineralogically and texturally similar or identical to sites of concern. Furthermore, the use of MAD in (3) reduces the effect of extremes often encountered in the tails of geochemical data, because the data in the tails have less influence on the calculation of the median than they do on the mean.

\subsubsection{Contamination Factors, Degree of Contamination, Modified Degree of Contamination and Pollution}

\section{Load Index}

Soils in the windward sites of the smelter stack were also assessed for contamination factors, degree of contamination, modified degree of contamination and the pollution load index, and the results are given in Table 3 .

Table 3. Contamination factors, degree of contamination, modified degree of contamination and pollution load index of the 7 studies elements

\begin{tabular}{cccccccc} 
& $\mathrm{Co}$ & $\mathrm{Cu}$ & $\mathrm{Fe}$ & $\mathrm{Mn}$ & $\mathrm{Ni}$ & $\mathrm{Pb}$ & $\mathrm{Zn}$ \\
\hline$C F$ & 0.36 & 6.36 & 1.40 & 1.02 & 3.64 & 2.16 & 1.21 \\
\cline { 2 - 3 }$C_{d}$ & 16.14 & & & & & & \\
$m C_{d}$ & 2.31 & & & & & & \\
$P L I$ & 1.63 & & & & & & \\
\hline
\end{tabular}

The assessment of soil contamination was carried out using the contamination factor and the degree of contamination, based on four classification categories recognised by Håkanson[15] whereas the modified degree of contamination, $m C_{d}$ classification and description [9] are given in Tables 4 and 5, respectively.

Table 4. Contamination factors and degree of contamination categories and terminologies

\begin{tabular}{ccc}
\hline$C F$ classes & $C F$ and $C_{d}$ terminologies & $C_{d}$ classes \\
\hline$C F<1$ & Low $C F$ indicating low & $C_{d}<8$ \\
& contamination $/$ low $C_{d}$ & \\
$1 \leq C F<3$ & Moderate $C F / C_{d}$ & $8 \leq C d<16$ \\
$3 \leq C F<6$ & Considerable $C F / C_{d}$ & $16 \leq C d<32$ \\
$C F \geq 6$ & Very high $C F / C_{d}$ & $C d \geq 32$ \\
\hline
\end{tabular}

Table 5. Modified degree of contamination classification and description

\begin{tabular}{cc}
\hline$m C_{d}$ classes & Modified degree of contamination level \\
\hline$m C_{d}<1.5$ & Nil to very low degree of contamination \\
$1.5 \leq m C d<2$ & Low degree of contamination \\
$2 \leq m C d<4$ & Moderate degree of contamination \\
$4 \leq m C d<8$ & High degree of contamination \\
$8 \leq m C d<16$ & Very high degree of contamination \\
$16 \leq m C d<32$ & Extremely high degree of contamination \\
$m C d \geq 32$ & Ultra high degree of contamination \\
\hline
\end{tabular}

The overall contamination of soils at the site, based on the $C F$ values indicate that soils were considerably contaminated with $\mathrm{Cu}$ and $\mathrm{Ni}$, moderately contaminated with $\mathrm{Fe}, \mathrm{Mn}, \mathrm{Pb}$ and $\mathrm{Zn}$, but showed signs of low contamination with Co. In the case of degree of contamination, the windward soils fall under considerable contamination. It should be noted however that, as pointed out earlier, the authors need not rely much on the $C_{d}$ values obtained here since our studied metals are not the same as those recognised by Håkanson[15] to satisfy classification terminologies specified in his study. The modified degree of contamination suggest that the studied area is moderately contaminated $\left(m C_{d}=2.3\right)$. Care must however be exercised on interpreting the $m C_{d}$ results since, as with any averaging procedure, spikes for individual elements may be hidden within the overall average result. For example, $\mathrm{Cu}$ falls under a high $m C_{d}$ category, whereas most other elements are within a nil to very low category. To minimise the effects of spikes of individual elements, a 
geometric mean can be considered instead. In this study, the geometric mean (also known as the pollution load index given in (7), suggests deterioration of site quality. Thus, an immediate intervention to ameliorate pollution at site is needed.

\subsubsection{Geoaccumulation Index}

The index of geoaccumulation was assessed based on the seven descriptive classes for increasing $I_{\mathrm{geo}}$ values proposed by Müller[28], depicted in Table 6 .

Table 6. Modified degree of contamination classification and description

\begin{tabular}{ccc}
\hline Value & Class & Description \\
\hline$I_{\mathrm{geo}}>5$ & 6 & Extremely contaminated \\
$4<I_{\mathrm{geo}} \leq 5$ & 5 & Strongly to extremely contaminated \\
$3<I_{\mathrm{geo}} \leq 4$ & 4 & Strongly contaminated \\
$2<I_{\mathrm{geo}} \leq 3$ & 3 & Moderately to strongly contaminated \\
$1<I_{\mathrm{geo}} \leq 2$ & 2 & Moderately contaminated \\
$0<I_{\mathrm{geo}} \leq 1$ & 1 & Uncontaminated to moderately \\
& & contaminated \\
$I_{\mathrm{geo}}=0$ & 0 & Uncontaminated \\
\hline
\end{tabular}

The calculated values of the $I_{\text {geo }}$ in soils windward of the copper-nickel smelter are discussed in conjunction with the $E F$ and the $C F$ results, presented in Figure 2.

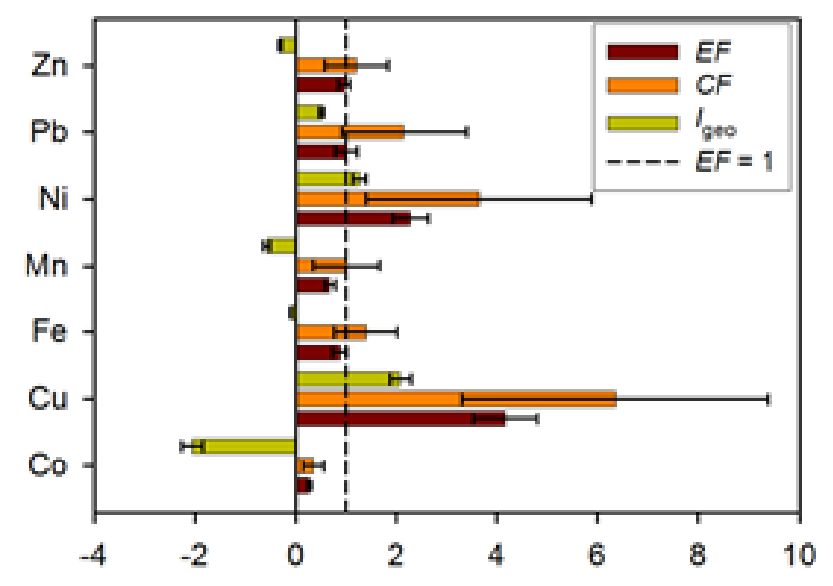

Figure 2. The enrichment factors, contamination factors and geoaccumulation factors

Data reveal uncontaminated to moderate contamination of soils by $\mathrm{Pb}$, moderate contamination by $\mathrm{Ni}$ and moderately to strong contamination by $\mathrm{Cu}$. The negative values in the $\mathrm{Co}$, $\mathrm{Fe}, \mathrm{Mn}$ and $\mathrm{Zn}$ indexes of geoaccumulation shown in Figure 2 are a result of deficient to minimal enrichment (Table 2) and/or relatively low levels of contamination (Table 3 ) as discussed earlier. Although the nature of the $I_{\mathrm{geo}}$ calculation, which involves the logarithmic function and a background multiplication factor of 1.5 , is somewhat different from other pollution calculation methods discussed in this study, the $I_{\text {geo }}$ factors are in general comparable to results reported for $E F s$ and $C F S$.

\subsection{Correlation Analysis}

Spearman's rho correlation analysis was performed between all variables for both sites. The level of significance $(P \leq 0.05$ and $P \leq 0.01)$ of multi-element correlation for soil samples was determined and the results are given in Table 7

Table 7. Spearman's rho correlation matrix of the seven elements from the two sites

\begin{tabular}{|c|c|c|c|c|c|c|c|}
\hline & $\mathrm{Co}$ & $\mathrm{Cu}$ & $\mathrm{Fe}$ & $\mathrm{Mn}$ & $\mathrm{Ni}$ & $\mathrm{Pb}$ & $\mathrm{Zn}$ \\
\hline \multicolumn{8}{|c|}{ Soils leeward of the mine } \\
\hline $\mathrm{Co}$ & 1 & & & & & & \\
\hline $\mathrm{Cu}$ & 0.42 & 1 & & & & & \\
\hline $\mathrm{Fe}$ & 0.45 & 0.20 & 1 & & & & \\
\hline $\mathrm{Mn}$ & $0.55 *$ & 0.30 & 0.33 & 1 & & & \\
\hline $\mathrm{Ni}$ & 0.50 & $0.85 * *$ & 0.37 & 0.37 & 1 & & \\
\hline $\mathrm{Pb}$ & 0.33 & 0.06 & 0.50 & -0.02 & 0.21 & 1 & \\
\hline $\mathrm{Zn}$ & -0.33 & 0.06 & 0.41 & -0.09 & 0.14 & $0.72 * *$ & 1 \\
\hline \multicolumn{8}{|c|}{ Soils windward of the mine } \\
\hline Co & 1 & & & & & & \\
\hline $\mathrm{Cu}$ & $0.45 *$ & 1 & & & & & \\
\hline $\mathrm{Fe}$ & $0.56 * *$ & 0.46 & 1 & & & & \\
\hline $\mathrm{Mn}$ & $0.70 * *$ & 0.15 & $0.61 * *$ & 1 & & & \\
\hline $\mathrm{Ni}$ & $0.55 * *$ & $0.70 * *$ & $0.57 * *$ & $0.60 * *$ & 1 & & \\
\hline $\mathrm{Pb}$ & 0.20 & $0.43 *$ & 0.29 & 0.30 & $0.76 * *$ & 1 & \\
\hline $\mathrm{Zn}$ & 0.07 & 0.17 & 0.45 & 0.30 & $0.56 * *$ & 0.32 & 1 \\
\hline
\end{tabular}

*. Correlation is significant at the 0.05 level (2-tailed).

**. Correlation is significant at the 0.01 level (2-tailed).

Inter-metallic correlations in lee soils were $\mathrm{Co}-\mathrm{Mn}, \mathrm{Cu}-\mathrm{Ni}$ and $\mathrm{Pb}-\mathrm{Zn}$. Association of $\mathrm{Co}$ with $\mathrm{Mn}$ suggests that the presence of cobalt in lee soils is pedogenic. Lack of association of $\mathrm{Cu}, \mathrm{Ni}$ with $\mathrm{Mn}$ and their significant correlation suggests anthropogenic origin presumably from possible intermittent release of smelter from the mine albeit the site's sheltered position. On the other hand, the $\mathrm{Pb}-\mathrm{Zn}$ pair may be due to vehicular emissions.

In the windward sites of the mine, the correlation trends were $\mathrm{Co}-\mathrm{Cu}, \mathrm{Co}-\mathrm{Fe}, \mathrm{Co}-\mathrm{Mn}$ and $\mathrm{Co}-\mathrm{Ni}$; $\mathrm{Cu}-\mathrm{Ni}$ and $\mathrm{Cu}-\mathrm{Pb}$; $\mathrm{Fe}-\mathrm{Mn}$ and $\mathrm{Fe}-\mathrm{Ni} ; \mathrm{Mn}-\mathrm{Ni} ; \mathrm{Ni}-\mathrm{Pb}$ and Ni-Zn. Earlier research on heavy metal content from various parts of Botswana soils (Mmolawa et al. 2011) reveal Fe, Mn to be predominantly lithogenic whereas $\mathrm{Cu}, \mathrm{Ni}, \mathrm{Co}, \mathrm{Pb}$ and $\mathrm{Zn}$ to originate from various anthropogenic sources. In this study, complex inter-elemental correlations revealed by windward soil results suggest mixed origin of sources. Thus, a multivariate principal component analysis was employed to help interpret these results as discussed below.

\subsection{Principal Component Analysis}

Relationships between variables at both leeward and windward sites of the mines are displayed in Table 8. In reference to eigenvalues, two principal components at both sites were extracted as they have eigenvalues greater than 1 . The bold values in Table 8 are the PC loadings greater than 0.5 , which are taken in the determination of principal components at both sites. 
Table 8. Factor loadings and communalities

\begin{tabular}{|c|c|c|c|c|c|c|c|}
\hline \multirow{2}{*}{ Element } & \multicolumn{3}{|c|}{ Rotated Matrix at Leeward Sites } & \multirow{2}{*}{ Element } & \multicolumn{3}{|c|}{ Rotated Matrix at Windward Sites } \\
\hline & $P C-1$ & $P C-2$ & Communalities & & $P C-1$ & $P C-2$ & Communalities \\
\hline $\mathrm{Ni}$ & 0.920 & 0.021 & 0.847 & $\mathrm{~Pb}$ & 0.856 & 0.060 & 0.739 \\
\hline $\mathrm{Cu}$ & 0.900 & -0.001 & 0.810 & $\mathrm{Ni}$ & 0.834 & 0.475 & 0.920 \\
\hline $\mathrm{Mn}$ & 0.865 & -0.158 & 0.772 & $\mathrm{Cu}$ & 0.675 & 0.270 & 0.529 \\
\hline Co & 0.465 & 0.216 & 0.263 & $\mathrm{Zn}$ & 0.588 & 0.132 & 0.363 \\
\hline $\mathrm{Pb}$ & -0.064 & 0.952 & 0.911 & Co & 0.131 & 0.894 & 0.816 \\
\hline $\mathrm{Zn}$ & -0.098 & 0.835 & 0.707 & $\mathrm{Mn}$ & 0.179 & 0.872 & 0.792 \\
\hline $\mathrm{Fe}$ & 0.411 & 0.665 & 0.612 & $\mathrm{Fe}$ & 0.400 & 0.716 & 0.673 \\
\hline Eigen Values & 2.803 & 2.119 & & Eigen Values & 2.437 & 2.391 & \\
\hline$\%$ of Variance & 40.043 & 30.277 & & $\%$ of Variance & 34.832 & 34.162 & \\
\hline Cumulative \% & 40.043 & 70.320 & & Cumulative \% & 34.832 & 68.994 & \\
\hline
\end{tabular}

At the leeward site, $P C-1$ accounted for $40 \%$ of total variance and was mainly characterised by high levels of $\mathrm{Ni}$, $\mathrm{Cu}$ and $\mathrm{Mn}$. Copper and nickel are normally associated with $\mathrm{Cu}-\mathrm{Ni}$ smelter emissions, whereas $\mathrm{Mn}$ is less expected to be associated with the smelter emissions (Steinnes et al. 2000). Thus, strong association of $\mathrm{Cu}$ and $\mathrm{Ni}$ with $\mathrm{Mn}$ at the site is mainly due to local lithology considering the site's leeward position relative to the smelter. On the other hand, $P C-2$ accounted for $30 \%$ of total variance with $\mathrm{Pb} ; \mathrm{Zn}$ and $\mathrm{Fe}$. Iron, lead and zinc are also commonly associated with $\mathrm{Cu}-\mathrm{Ni}$ smelter emissions [30]. Furthermore, $\mathrm{Pb}$ and $\mathrm{Zn}$ are also associated strongly with vehicular emissions. Considering the close proximity of this site to the road, constituents of $P C$-2 may not infer contributions from the smelter emissions. It is difficult to account for the existence of Co in the leeward soils, based on its low $P C$ loading.

At the windward site, $P C-1$ accounted for $35 \%$ of total variance and was characterised by $\mathrm{Pb}, \mathrm{Ni}, \mathrm{Cu}$ and $\mathrm{Zn}$ and is strongly associated with contributions from the $\mathrm{Cu}-\mathrm{Ni}$ smelter emissions affecting the site. On the other hand, $P C-2$ accounted for $34 \%$ of total variance and was characterised by $\mathrm{Co}, \mathrm{Mn}$ and $\mathrm{Fe}$ and is strongly associated with contributions from natural processes at the site.

\section{Conclusion}

Assessment of pollution in soils by heavy metals in the leeward and windward sites of the Selebi Phikwe copper nickel mine was evaluated using enrichment factors, modified degree of contamination, pollution load index and geoaccumulation index. Degree of enrichment was examined by comparing present day soil metal contents obtained using actual Fe pristine concentrations with standard earth material obtained from literature.

Only $\mathrm{Cu}, \mathrm{Fe}, \mathrm{Ni}$ and $\mathrm{Pb}$ concentrations in windward soils exceeded those at the leeward sites, suggesting anthropogenic input possibly through deposition of toxic substances associated with copper-nickel smelter emissions.

Enrichment factors of $\mathrm{Co}, \mathrm{Cu}$ and $\mathrm{Pb}$ were distinctively $(P$ $<0.05$ ) variable between methods and suggest that using $\mathrm{Fe}$ concentrations from standard earth material (Methods 1-3) as a normaliser produces higher $E F$ values as compared to average values determined using the $\mathrm{Fe}$ content obtained from uncontaminated soils adjacent to the study site. The authors suggest method 4 to be the most relevant in this study of enrichment factor determination of heavy metals at the study site. Results obtained using pristine background metal content values demonstrate moderate enrichment of $\mathrm{Cu}$ and $\mathrm{Ni}$ in the superficial layer of soils windward the Selebi Phikwe copper-nickel mine.

With regard to the overall contamination of soils at the studied site, a modified form of degree of contamination equation by Håkanson[15], which determines an average value of individual $C F$ values of the studied metals, is proposed. Based on this approach, the modified degree of contamination $\left(m C_{d}=2.3\right)$ revealed moderate contamination by the studied metals. On the other hand, geometric mean of the $C F$ values suggests deterioration of site quality. Thus, a call for interventions to ameliorate pollution at the site is proposed.

Although the nature of calculating geoaccumulation indices $\left(I_{\mathrm{geo}}\right)$ is somewhat different from pollution calculation methods discussed in this study, the $I_{\text {geo }}$ obtained from the studied metals are generally comparable to results reported for $E F s$ and $C F s$.

Multivariate principal components analysis indicate some degree of anthropogenic influence possibly by smelter emissions in the presence of $\mathrm{Pb}, \mathrm{Ni}, \mathrm{Cu}$ and $\mathrm{Zn}$. Strong positive loadings of $\mathrm{Co}, \mathrm{Mn}$ and $\mathrm{Fe}$ are associated with contributions from natural processes. 
This study revealed the need for further detailed metal enrichment assessment to decrease the uncertainty of discrimination between lithogenic and anthropogenic origins at the sites.

\section{Acknowledgements}

The authors are gratefully acknowledging the financial support of the Research and Publications Committee (RPC) of the Botswana College of Agriculture. The authors also highly appreciate the work done by Mr R. Tlhong of the University of Botswana for providing assistance with analysis of samples.

\section{REFERENCES}

[1] P W. Abrahams. Soils: Their implications to human health, Science of the Total Environment Vol.291, 1-32, 2002.

[2] J. L Schroeder, N. T. Basta, S. W. Casteel, T. Evans, T. J. Payton, J. Si. Validation of the in vitro intestinal (IVG) method to estimate relative bioavailable lead in contaminated soils. Journal of Environmental Quality, Vol.33, 513-521, 2004.

[3] H. W. Mielke, K. J. Berry, P. W. Mielke, E. T. Powell, C. R. Gonzales. Multiple metal accumulation as a factor in learning achievement within various New Orleans elementary school communities, Environmental Research, Vol.97 No.1, 67-75, 2005.

[4] O. Selinus, B. Alloway, J. A. Centeno, R. B. Finkelman, R. Fuge, U. Lindh, P. Smedley. Essentials of medical geology, impacts of the natural environment on public, Health, Vol. 144, 890-891, 2005.

[5] F. Reboredo. How differences in the field influence $\mathrm{Cu}, \mathrm{Fe}$ and $\mathrm{Zn}$ uptake by Halimione portulacoides and Spartina maritima, The Science of the Total Environment, Vol.133, 111-132, 1993.

[6] F. Reboredo. Cadmium Accumulation by Halimione portulacoides (L.) Aellen. A Seasonal Study, Marine Environmental Research, Vol.33, 17-29, 1992.

[7] S. C. Sheppard. Geophagy: Who eats soil and where do possible contaminants go? Environmental Geology, Vol.33, No.2-3, 109-114, 1998.

[8] H. H. Huu, S. Rudy, A. V. Damme. Distribution and contamination status of heavy metals in estuarine sediments near Cau Ong Harbour, Ha Long Bay, Vietnam, Geology Belgica, Vol.13, 37-47, 2010.

[9] G. M. S. Abrahim, P. J. Parker. Assessment of heavy metal enrichment factors and the degree of contamination in marine sediments from Tamaki Estuary, Auckland, New Zealand, Environmental Monitoring and Assessment, Vol.136, No.1-3, 227-238, 2008.

[10] E. R. Long, D. D. MacDonald, S. L. Smith, F. D. Calder. Incidence of adverse biological effects within ranges of chemical concentrations in marine and estuarine sediments.
Environmental Management, No.19, 81-97, 1995.

[11] R. Chester, W. M. Kudoja, A. Thomas, J. Towner. Pollution reconnaissance in stream sediments using non-residual trace metals, Environmental Pollution, Vol.23, 213-238, 1985.

[12] D. M. Gaiero, G. R. Ross, P. J. Depetris, S. Kempe. Spatial and temporal variability of total non-residual heavy metals content in stream sediments from the Suquia River system, Cordoba, Argentina, Water, Air, and Soil Pollution, Vol.93, 303-319, 1997.

[13] R. A. Sutherland, C. A. Tolosa, F. M. G. Tack, M. G. Verloo. Characterization of selected element concentration and enrichment ratios in background and anthropogenically impacted roadside areas, Archives of Environmental Contamination and Toxicology, Vol.38, 428-438, 2000.

[14] K. B. Mmolawa, A. S. Likuku, G. K. Gaboutloeloe. Assessment of heavy metal pollution in soils along major roadside areas in Botswana, African Journal of Environmental Science and Technology, Vol.5, 186-196, 2011.

[15] L. Håkanson. Ecological risk index for aquatic pollution control. A sedimentological approach, Water Research, Vol.14, 975-1001, 1980.

[16] G. Qingjie, D, Jun, X. Yunchuan, W. Qingfei, Y. Ligiang. Calculating pollution indices by metals ecological geochemistry assessment and a case study in parks of Beijing. Journal of China University of Geosciences, Vol.19, 230-241, 2008.

[17] C. Nikolaidis, I. Zafiriadis, V. Mathioudakis, T. Constantinidis. Heavy metal pollution associated with an abandoned lead-zinc mine in the Kirki region, NE Greece, Bulletin of Environmental Contamination and Toxicology, Vol.85, 307-312, 2010

[18] FAO. Soil Map of the Republic of Botswana. Soil Mapping and Advisory Services Project. AG:DP/BOT/85/011. Ministry of Agriculture, Gaborone Botswana/FAO/UNDP, 1990.

[19] A. S. Likuku, G. K. Gaboutloeloe, K. B. Mmolawa. Determination and source apportionment of selected heavy metals in aerosol samples collected from Sebele, American Journal of Environmental Sciences, Vol.9, No.2, 188-200, 2013.

[20] P. Buat-Menard, R. Chesselet. Variable influence of atmospheric flux on the trace metal chemistry of oceanic suspended matter, Earth and Planetary Science Letters, No.42, 398-411, 1979.

[21] W. Salomons, U. Förstner. Metals in the Hydrocycle (Tokyo) Springer p 349, 1984.

[22] K. K. Turekian, K. H. Wedepohl. Distribution of elements in some major units of the Earth's crust, Geological Society of America, Bulletin 72, 175-192, 1961.

[23] S. R. Taylor. Abundance of chemical elements in the continental crust: a new table. Geochimica et Cosmochimica Acta, Vol.28, 1273-1285, 1964.

[24] K. H. Wedepohl. The composition of the continental crust. Geochimica et Cosmochimica Acta, Vol.59, 1217-1232, 1995. 
[25] S. R. Taylor, S. M. McLennan. The geochemical evolution of the continental crust, Reviews of Geophysics, Vol.33, 241-265, 1995.

[26] G. M. S. Abrahim. Holocene sediments of Tamaki Estuary: Characterization and impact of recent human activity on an urban estuary in Auckland, New Zealand, PhD Thesis University of Auckland, Auckland (New Zealand), p. 361, 2005.

[27] D. L. Tomlinson, J. G. Wilson, C. R. Harris, D. W. Jeffrey. Problem in the assessment of heavy metals levels in estuaries and the formation of a pollution index, Helgoländer
Meeresuntersuchungen, Vol.33, 566-575, 1980.

[28] G. Müller. Index of geoaccumulation in sediments of the Rhine river, Geojournal No.2, 108-118, 1969.

[29] V. Barcan. Nature and origin of multicomponent aerial emissions of the copper-nickel smelter complex, Environment International, Vol.28, 451-456, 2002.

[30] E. Steinnes, N. Lukina, V. Nikonov, D. Aalmlid, O. Røyset. Gradient study of 34 elements in the vicinity of a copper-nickel smelter in the Kola Peninsula, Environmental Monitoring and Assessment, Vol.60, 71-78, 2000. 